\title{
HIGH-SPEED RAILWAY AND TOURISM: IS THERE AN IMPACT ON INTERMEDIATE CITIES? EVIDENCE FROM TWO CASE STUDIES IN CASTILLA-LA MANCHA (SPAIN)
}

\author{
Carmen VÁZQUEZ VARELA, José M. MARTíNEZ NAVARRO \\ University of Castile-La Mancha, Spain
}

\begin{abstract}
The expectations of cities served by High Speed Rail are numerous Improvements in a destination's accessibility could lead to an increase in transport demand and the revitalization of urban and business tourism. However, High Speed Rail services do not automatically affect the choice of destination even if they improve accessibility. Even so, they can improve visitation rates when tourist amenities are located near High Speed Rail stations becoming therefore easily accessible. The development of tourism is also influenced by the collective strategies of local stakeholders. Larger cities also appear able to leverage higher tourist volumes from the construction of High Speed Rail and most analyses to date have focused upon them. Thus we focus here on how the arrival of High Speed Rail services has impacted tourism on medium sized cities. Using a diachronic study of different socio-economic variables and tourist features, this article analyses the impact that the new rail infrastructure can have on tourism in two selected cases in Spain: Cuenca and Toledo.
\end{abstract}

Key Words: high speed rail, tourism, urban development, Cuenca, Toledo

\section{Introduction}

Transportation and tourism are closely related economic activities. In fact, promoting transportation infrastructure and guaranteeing efficient mobility are usually seen as contributing to the development of tourism industry (Albalate and Fageda 2016). Amongst the multiple determinants of the attractiveness of a particular location from the point of view of tourism, accessibility usually ranks in the first two or three positions. A beautiful landscape, a historical monument or a sunny and fine sandy beach hardly becomes a clear successful tourist destination if transport infrastructure does not allow a convenient, comfortable and safe way to get there and return. This issue is particularly relevant for Spain, a country that shares the feature of being one of the world's favourite tourist destinations while having Europe's largest high-speed rail network (second in the world after China) (Albalate et al. 2015). Furthermore, city size appears to be a major determinant of high speed rail's (HSR) impact on tourism (Delaplace 2012b). Thus, Bazin et al. (2013) reported that the increase in the number of tourists attributable to a new HSR service was minimal in many small and medium-sized European cities, although positive effects were detected in those places with good tourist amenities.

This article aims, first, to debate the theoretical impact that new HSR infrastructure has on tourism. Secondly, it analyses the effects on tourism of such infrastructure in two selected cities, Cuenca and Toledo, from several different perspectives - improved accessibility; growth in both visitor numbers and tourism-related businesses; improved image of tourist attractions; and the emergence of development strategies among stakeholders to market and enhanced visitor experiences, and therefore greater patronage. Nonetheless, any conclusions drawn from this article must take into account the short period of time since the completion of the HSR network to Cuenca and Toledo and its likely lagged effects on tourist visitation. In addition, 
HSR's impact is likely to be affected by such extraneous events as the global financial crisis and its aftermath. After explaining the development of Spain's HSR network and the development of our theoretical and methodological framework, we will briefly characterize the selected cities' contrasting tourism models both before and after the completion of the HSR. This section will focus on their defining features and the range and quality of attractions. Finally, we will consider the potential future impact the new infrastructure might have in the light of various assumptions.

\section{The development of Spain's high-speed rail network}

The main reason behind the birth of HSR in Europe, over and above other economic and political factors, was to unite large metropolitan centres and to realise the commercial benefits arising from the speed and efficiency of transport between them (Troin 1997, Vickerman 2015). This is particularly important for cities between 400 and $600 \mathrm{~km}$ apart (Vickerman 2016), where operating speeds of $250 \mathrm{~km} / \mathrm{h}$ or higher between their commercial cores could generate substantial advantages over air transport, with travel times of less than three hours (Hall 2009). Subsequently, in both France (Troin 1998) and then Spain, which largely adopted the French model and network structure, intermediate stops appeared along HSR routes. For example, when the second generation of French HSR routes commenced back in the 1990s, the TGVMediterrannée and TGV Atlantique, the intermediate territories defended their interests claiming that they would suffer all environmental costs involved in the construction of a new line, but they would not receive any of the alleged benefits associated with greater accessibility through the HSR stations (the well-known "tunnel effect"). Railway managements accepted the claim that intermediate stops on the new lines could expand the potential market (FacchinettiMannone et al. 2013). Additional justifications for intermediate stops included political integration, economic restructuring and territorial cohesion. Such claims were based on the assumption, widespread among public opinion and political environment, that HSR promotes growth and territorial development, an argument which, as shown in other studies, it is not always true (Bellet et al. 2010, Albalate and Bel 2015). Spain's response to local pressures along HSR routes created even more intermediate stops than in France, having approximately one station every $70 \mathrm{~km}$.

Spain's AVE (Alta Velocidad Espanola) has "dedicated, high-speed, standard-gauge tracks that serve both high-speed and conventional trains equipped with a gauge-changing system, and conventional, nonstandard gauge tracks that serve only conventional trains" (Todorovich et al. 2011: 8). Perl and Goetz (2015) have labelled the Spanish model as a comprehensive national network with extensive new infrastructure development linking major cities and mid-sized communities across the country while using a predominantly radial network centred on Madrid. High speed rail services in Spain commenced on April 21, 1992 with the opening of the $471 \mathrm{~km}$ Madrid-Seville $(471 \mathrm{~km})$ southern corridor. By choosing Seville as a destination, Spain became the only European nation not to commence its HSR services along its most congested corridors or to connect its most populated cities. However, we acknowledge that the conventional southern link was arguably somewhat congested. Several studies point to a political rationale for this strategy, namely the promotion of economic development in one of the country's poorer regions and thereby assisting the national cohesion through improved territorial equity, albeit at a high economic and social cost to the nation (Sala-i-Martin 1997, Albalate and Bel 2012).

This first rail line brought five HSR stations into use. Table 1 shows the subsequent HSR network expansion since 2003 starting with several strategic axes: Madrid-Barcelona-French border (this HSR line came into service in four stages corresponding to the following stretches of track: Madrid-Lleida, Lleida-Camp de Tarragona, Camp de Tarragona-Barcelona-Sants, Barcelona-Girona-Figueres); Madrid-Levante; and Madrid-Northwest (unfinished). Many additional rail connections such as Cordoba-Malaga and Madrid-Toledo, has yielded a network of more than 3100 kilometres of high-speed lines (LAV) today, connecting 31 cities through 36 
HSR stations and serving more than $60 \%$ of the Spanish population. According to the operating company, 9 out of 10 citizens currently live less than 30 kilometres from a HSR station. In 2015, more than 33 million passengers per year used high-speed trains, travelling at an average commercial speed of $222 \mathrm{~km} / \mathrm{h}$, higher than Japan's $218 \mathrm{~km} / \mathrm{h}$ and France's $216 \mathrm{~km} / \mathrm{h}$. However, this situation contrasts markedly with HSR ridership (number of trips) figures, which show that ridership is much higher in France, Germany and Italy despite their more limited networks. While ridership in Japan is well over 300 million, and over 110 million in France, the number of trips on the Spanish HSR network is much smaller (almost 31 million in 2015), and if we consider the intensity of network use (passenger-km per $\mathrm{km}$ of network), the ridership in France is five times higher than in Spain, while in Germany and Italy it is 4.4 and 2.6 times higher (Albalate and Fageda 2016).

Different scholars consider that high-speed railway is able to compete with the private vehicle avoiding the traffic congestion problems in the environment and entry to major cities for distances less than $400 \mathrm{~km}$. However, some authors have questioned the hypothesis of replacing part of air traffic by the opening of high-speed lines, taking into consideration the pace and shaping of the Spanish HSR network, as well as the impact of specifically demandinduced by HSR (Guirao Abad 2000), clearly influenced by the location of the HSR station. Analyses of substitution between the two transport modes confirm the hypothesis that HSR and the airlines would seem to offer more independent services than it might first appear. As some experts have cleverly pointed out, a huge range of dynamics operate here, such as the rise of budget airlines. The need of airline passengers to connect with on-going flights and intermediate airports (especially connecting to international flights), and the issue of flight frequency and the number of flights per day between two cities seem to be expanding constantly.

The results of some research apparently confirm the hypothesis of the HSR's great ability to generate its own demand (Castillo-Manzano et al. 2015). The substitution rate between the two transport modes seems to be closely linked to the way that any new stations are incorporated into the HSR network. Although the rate varies significantly over the study period, only $13.9 \%$ of HSR passenger demand was found to have come from air travel during the 1999-2012 period. Thus, even in the most geographically extensive HSR 'network' in the world compared to the surface area involved, the Iberian Peninsula, there is no empirical evidence at all that the network has generated any clear network effects that will attract more passengers from air transport. In other words, the expansion of the network, with some lines offering less than doubtful social profitability and clearly following political criteria (Bel 2011), has seen the substitution rate with air transport falling over many years (Castillo-Manzano et al. 2015).

The program for the trans-European transport network (TEN-T), as introduced under the Treaty of Maastricht and defined in the Decision 1692/96/EC in 1996, is designed to guarantee optimum mobility and coherence between the various modes of transport in the Union. The TEN-T focuses significantly on the development of high speed transport. Of the 30 priority projects put forward under this program, no fewer than 14 concern high-speed lines. Of those, only three high-speed railway lines have been labelled as priority axes and projects establishing connections between major cities on the Iberian Peninsula, and linking them with the French high-speed network. New high-speed railway lines (built to standard European gauge in Spain and Portugal) will link Lisbon and Porto to Madrid. However, for the time being, and given the economic difficulties, both projects have been cancelled by the Portuguese government. From Madrid, two branches - Atlantic and Mediterranean - will connect to the French HSR network. In Spain, in addition to support from TEN-T funds, development work is also receiving substantial support from the Cohesion Fund.

In Spain, the network layout and the choice of rail lines has not so far given priority to population density and possible traffic density. Current infrastructure plans are however 
Chronology of high-speed railway lines and stations in Spain

\begin{tabular}{|c|c|c|}
\hline Opening date & High-Speed Rail line & High-Speed Rail stations in Spain \\
\hline April 1992 & Madrid-Sevilla & $\begin{array}{l}\text { Madrid Atocha, Ciudad Real, Puer- } \\
\text { tollano, Córdoba, Sevilla }\end{array}$ \\
\hline October 2003 & $\begin{array}{l}\text { Madrid-Barcelona-French bor- } \\
\text { der }\end{array}$ & $\begin{array}{l}\text { Guadalajara-Yebes, Calatayud, Zara- } \\
\text { goza-Delicias, Lleida-Pirineus }\end{array}$ \\
\hline November 2003 & Zaragoza-Huesca & Huesca, Tardienta \\
\hline November 2005 & Madrid-Toledo & Toledo \\
\hline December 2006 & $\begin{array}{l}\text { Madrid-Barcelona- French } \\
\text { border }\end{array}$ & Camp de Tarragona \\
\hline December 2006 & Córdoba-Málaga & Antequera Santa Ana, Puente Genil \\
\hline December 2007 & Madrid-Valladolid & $\begin{array}{l}\text { Madrid-Chamartín, Segovia-Guiomar, } \\
\text { Valladolid }\end{array}$ \\
\hline December 2007 & Córdoba-Málaga & Málaga-María Zambrano \\
\hline February 2008 & $\begin{array}{l}\text { Madrid-Barcelona- French } \\
\text { border }\end{array}$ & Barcelona-Sants \\
\hline December 2010 & $\begin{array}{l}\text { Madrid-Barcelona- French } \\
\text { border }\end{array}$ & Figueres \\
\hline December 2010 & Madrid-Valencia-Murcia & $\begin{array}{l}\text { Cuenca, Albacete, Requena-Utiel, } \\
\text { Valencia }\end{array}$ \\
\hline December 2011 & Madrid-Galicia- Atlantic axis & $\begin{array}{l}\text { Ourense, Santiago de Compostela, } \\
\text { A Coruña }\end{array}$ \\
\hline January 2013 & $\begin{array}{l}\text { Madrid-Barcelona- French } \\
\text { border }\end{array}$ & Girona \\
\hline June 2013 & Madrid-Valencia-Murcia & Villena, Alicante \\
\hline March 2014 & Madrid-Sevilla & $\begin{array}{l}\text { Villanueva de Córdoba-Los } \\
\text { Pedroches }\end{array}$ \\
\hline April 2015 & Madrid-Galicia- Atlantic axis & Vigo-Urzaiz \\
\hline September 2015 & Valladolid-León & Palencia, León \\
\hline December 2015 & Madrid-Galicia & Zamora \\
\hline
\end{tabular}

Source: Authors' data based on ADIF information

addressing the HSR connection of provincial capitals to a network centred in Madrid, emphasizing their important relations with the National Capital as formulated by the former Prime Minister José María Aznar on 25 April 2000. Political-administrative and territorial issues have therefore come to the forefront over the efficiency and cost of transport (Guirao Abad 2000, Albalate and Bel 2015). Thus, the rationale for extending the network in Spain is to fulfil the political aim of centralizing rail connections, and, only in a few cases, the projects under the Trans-European transport network (TEN-T) had priority and affected the local decisions. Many intermediate stops serve small and medium size cities located in areas of low population density, whose urban polarities are little (or poorly) defined (Garmendia et al. 2012). Thus many new HSR stations were located without distorting the planned route of the railway line and placed on the edges of such cities or even in their periphery (Bellet Sanfeliu and Jurado Rota 2014), while in major urban centres stations retained their central location (Fig. 1). In other words, in the case of intermediate stops, the economic logic of transport efficiency takes pride of place over other needs, ignoring the existing urban and territorial structures (Vickerman 
et al. 1999). This can be justified because the traffic that really justifies HSR investment is mostly generated by large cities and the only way to minimize slower travel times, at a reasonable cost, is to locate stations on the periphery of small to intermediate cities (Bellet 2016).

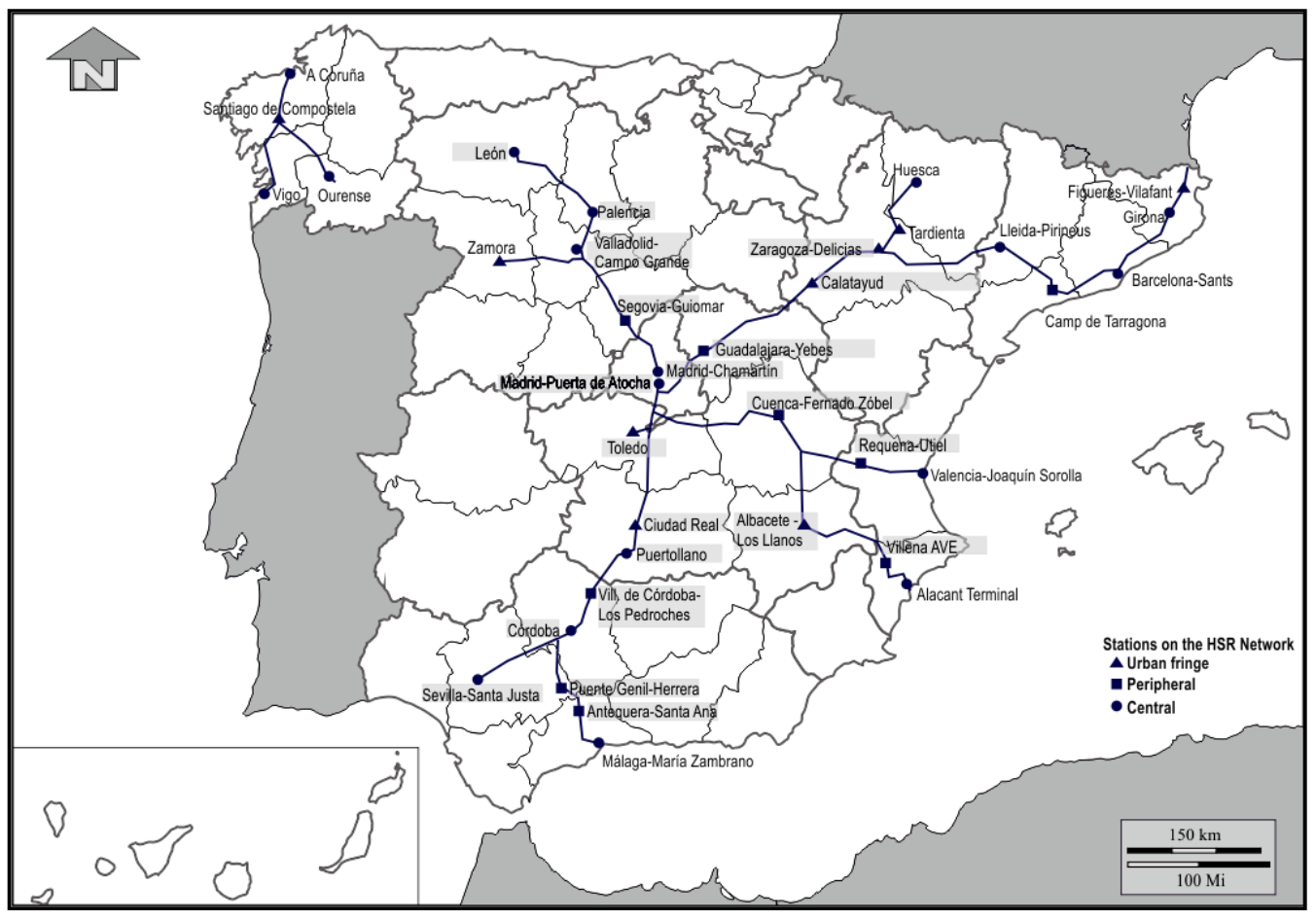

Fig. 1 - HSR Spanish lines and stations (September 2016) Source: updated from Bellet 2016: 46

Nevertheless, it should be remembered that passengers are not necessarily concerned with the station-to-station travel time when deciding their choice. Door-to-door travel time is of importance, together with the convenience and reliability, and the cost (an element we do not deal with here) of the entire chain of journeys from the beginning to end of a trip (Givoni and Banister 2012: 306). The characteristic of HSR, like with air travel, often means that most of the travel time (and effort) is spent on getting to and from the HSR station, and this constitutes the bulk of the journey travel time (Bellet et al. 2010). Givoni and Banister (2012: 307) argue that there are two important consequences arising from this fact. First, HSR travel can be not attractive for many travellers, despite its faster speed compared to other modes, especially when the origin and/or the destination are not in the city centre. Second, any time savings on the rail journey from the high speed section might be lost on the additional time taken for access and/or egress journeys to/from the HSR station. Finally, in the trade-off between the time spent on the train and on getting to it, some experts say that it is likely that passengers will prefer to reduce the access time (Brons et al. 2009).

Such arguments in favour of locating intermediate stations closer to city centres voiced by local residents or transport and urban planners seeking reduced access times may however be overstated to maximise, if possible, local convenience. Of course peripheral HSR stations 
extend access times and therefore overall trip length and lose one of the main virtues of rail transport when HSR stations are located within a built-up area or even the city centre (Vickerman et al. 1999). Another urban and physical planning problem centres on the difficulty of articulating the new fringe HSR transport nodes (Bertolini 1996) with the existing urban fabric and territorial structure. Despite these observations, peripheral locations may create development opportunities, because around the new HSR station there is usually available land at affordable prices to promote new industrial, commercial or even residential centres. On the other hand, such locations may have little immediate development potential for communities struggling to retain their populations or where connections to other transportation options (mixed-mode commuting) are poorly developed. Thus, it could take decades to acquire activities normally associated with a railroad stop. In France, some cases of HSR stations located in the urban periphery have favoured new developments and real estate activities in their immediate surroundings, especially those related to the activities of the advanced tertiary sector. But in fact there has been little identifiable local economic development associated with many of these HSR stations: either they have attracted only few new activities or the activities have not been those initially desired (Facchinetti-Mannone and Bavoux 2010).

In some cases, the choice of location, away from the built-up urban area, and the poor connectivity with the local or regional transportation network, have caused a loss of opportunities that has involved modest levels of services and railway traffic. As a result, the peripheral HSR stations tend to give poorer results in terms of traffic and services (Preston and Wall 2008). To what extent the distance from the HSR station hampers to potential tourist flows is an enigma that we will consider in this paper. In any case, some of the examples that we will detail here have reached neither the expected number of passengers nor the number of services intended, or the desired economic impact. And this has a cumulative effect, because train operators are reluctant to build additional railway stations with high-speed services, especially when final journey times are critical in relation to competition to air transport, so that services are reduced and these become less attractive to potential users.

\section{High speed rail and tourism: conceptual background}

Interestingly, most traditional theories and models proposed to explain the development of tourism and preferred destinations have not identified transport as a major factor in the process. In fact, the analysis of its role is often underestimated and, following some scholars: "Little serious research has been undertaken into the significance of transport as a factor in destination development" (Prideaux 2000: 54). Nevertheless, "transport is intrinsically linked to tourism behaviour since, by definition, the tourist is a traveller" (Delaplace et al. 2014a: 2).

However, the last decade has seen several important studies that have focused on the interactions between HSR systems and the tourism market. These include work by authors from France (Masson and Petiot 2009, Delaplace et al. 2014a, Delaplace et al. 2014b), Italy (Pagliara et al. 2013, Pagliara et al. 2015), China (Wang et al. 2012) and Spain (Guirao and Soler 2008, Gil Álvarez 2010, Albalate and Fageda 2016). Some of these studies assume that new transport infrastructure will result automatically in a substantial improvement of accessibility, influencing tourism in two interconnected ways. Firstly, there will be potential sources of new tourists and, in that sense, the enlargement of demand-side markets; and, secondly, changes in the existing patterns of tourist flow, spreading them more evenly across the year. In short, where HSR projects exist, the analysis shows the idea that the commissioning of a HSR line should benefit the tourism sector: "Besides business journeys, tourism is the first sector to show an immediate effect following the inauguration of an HST line. Indeed, the number of tourists in cities linked to the network tends to increase thanks to this alternative mode of transport" (Albalate and Bel 2012: 345). A larger volume of tourist traffic would increase turnover in the sector and generate higher tax revenue from visitor expenditure, while its less marked seasonality would provide more balanced occupation of accommodation 
throughout the year. This rationale is based on the weight of business tourism and weekendshort stays of urban/cultural tourism. However, decreasing seasonality could come from sources other than better HSR access. Such variables could include higher holiday allowances, greater wealth and income, and an ageing population with greater propensity to travel, higher car ownership, and so on.

Furthermore, other specialists continue to point out that if the station is located in the city centre, places of urban tourism are more easily accessible without loss of time for tourists. A HSR service allows visitors to access their destinations faster and with less fatigue, by avoiding congestion and navigation difficulties in the heart of cities, especially when travelling by car. These benefits are even greater when the station is located close to the city centre. It may also allow foreign tourists visiting major cities to select a secondary destination that can be visited during the day with a round trip by train (Delaplace et al. 2014a). Notwithstanding these benefits, the role of transport infrastructure in tourism development could be ambiguous. In the case of the HSR, the effects may be conditioned by the existing tourism resources. The direction of causality is often very unclear. It is also true that the most optimistic expectations may be obscured by the fact that this transport improvement is often synonymous with the reinforcement of spatial competition between tourism destinations.

Since the 1970s, the belief that improvements to transport access through HSR implementation could trigger wealth and prosperity was gradually abandoned. It was realised that the local portfolio of tourist attractions and the strategies developed to enhance them were just as important. This new realization thereby modifies the cause and the effect relationships between the investment in the transport infrastructure and an expanded role for tourism in the economies served by HSR. In short, the effects depend on the space economy in which the HSR fits (Masson and Petiot 2009), and the conditions that led to the appearance of these impacts include: a) the existence of strong local potentialities; b) the existence of local strategies; c) the development of specific aspects of the tourism sector such as urban tourism and business tourism (Masson and Petiot 2009).

Accordingly, although expectations were important in France, Italy and Spain, a literature review of studies carried out ex-post shows that the effects are not systematic, since "they depend on the implementation of the HSR service and on the characteristics of the territories. It can be noted that, if the high speed rail allows, in some cases, the increase in the number of tourists, a decrease of the stay may follow. To understand the role of HSR, it is necessary to take into account the changes of accessibility, but also its effects on the image of the destination and on the coordination of the stakeholders" (Delaplace et al. 2014a: 1). The arrival of an HSR service in cities might generate high expectations of improved tourism, but this is yet to be demonstrated because the results of various studies are often contradictory.

Two revealed preference surveys were carried out in Rome in April 2012 (Pagliara et al. 2013), and in Paris in October 2012 (Delaplace et al. 2014b). The objective was to investigate the role of HSR in the choice of destination for tourism purposes and on the probability of visiting other cities and returning to Paris or to Rome. In the case of Rome, only $26 \%$ of the respondents were positively influenced by the presence of the HSR for the destination choice, but in Paris, $49 \%$ of the respondents were positively influenced by the presence of HSR in the destination choice. Apparently, several factors influence the choice of tourists, like the presence of architectural sites, the quality of promotion of the destination itself, the presence of special events, but the HSR system has affected the choice of Paris and Rome differently. The authors argue that "the two cities belong to two different countries in which the history of HSR service was very different; in France HSR was considered a real transport mode alternative, while in Italy it was a relatively new system, with high travel costs, which still needs a campaign of promotion to be well accepted among the users and therefore the tourists" (Delaplace et al. 2014b: 174). However, as some experts pointed out, Paris is much more central within Europe 
and both France and neighbouring countries to the north and east are perhaps more wealthy than Rome and Madrid hinterlands. Also, Paris has for a long time been a premier tourist destination and it is higher on the tourist 'radar' than Rome or Madrid (Berger 2015).

A year later, in June 2013, a new survey on tourists' choice of a destination was conducted in Madrid (Pagliara et al. 2015). In this case, the preliminary results showed that the Spanish HSR system seems to have a significant effect on the tourists' choice to visit other cities close to Madrid, but the choice of Madrid as a tourist destination is not influenced by the presence of HSR, while other factors play a significant role. The conducted questionnaire has shown that, in general terms, domestic and foreign tourists have different characteristics and behaviours. Therefore, the implementation of tourist products specifically adapted to each demand segment seems essential to strengthen the tourist attraction in a competitive environment (Pagliara et al. 2015: 193). HSR shows great attractiveness for foreign tourists, as they generally value aspects such as comfort and travel time reductions, and they are generally less sensitive to ticket prices. Thus, in Spain, the public institutions dealing with the tourism promotion specifically and those involved in the regional development strategy seem to be aware of that. Some steps to promote the use of HSR by the foreign tourists have been taken in the right direction, such as the creation of the Avexperience consortium and the implementation of the Spain Pass (Pagliara et al. 2015: 194).

The analysis conducted by Bazin et al. (2013) in some small and medium-sized cities in Northern, Atlantic and Eastern Europe served by HSR shows that, despite an improvement in the accessibility even in cities with a tourist heritage, the increase in tourists due to HSR is minimal. For cities of intermediate size, positive effects can be discerned, provided that they have strong 'basket of tourist goods' in terms of number, quality and diversity. Spanish effects are similar to those in France and Ureña et al. (2009) argue that such large intermediate cities served by HSR, as Lille, Zaragoza or even Cordoba, are likely to see a growth in urban and business tourism. Similarly, Todorovich et al. (2011) reported that, since the start of the HSR service in Lleida in 2003 and until 2009, tourist visitation has increased by about 15 percent and the demand for business conventions has risen 20 percent. However, they emphasize that this was not the case of Tarragona, because of the remoteness of the station relative to the most attractive coastal areas. An increase of tourist movements is however mentioned in Taiwan (Cheng 2010) or in China, where some cities have benefited from a HSR service (Wang et al. 2012). Provinces served in China by HSR "are likely to have approximate 20 percent additional numbers of foreign arrivals and 25 percent greater tourism revenues than provinces without such systems" (Chen and Haynes 2012: 1).

Thus, it seems clear that the tendency to generalize is wrong because some positive impacts identified in certain types of cities, with specific strengths, are not always applicable to others. As noted by some experts, "accessibility to infrastructure is (...) seen as an initial condition for development by a large number of political actors, this indicating a widespread confusion between accessibility and attractiveness" (Berion et al. 2007: 655). The extreme heterogeneity of tourist and business destinations underlines their necessary contextualization (Delaplace 2012a). HSR and its commercial, cultural or demographic effects cannot be understood independently of the socio-economic characteristics of the served areas, in tourism as in the other contexts (Bazin et al. 2013). Moreover, we must take into account some possible complicating issues (Levinson 2012). For example, if the number of tourists increases, the duration of their stay, in some cases, can be reduced. HSR allows the arrival and departure during a single day. Furthermore, this reduction in length of stay might also reflect the strategies of some businesses to move to day-long meetings in order to reduce travel budgets.

The most recent analyses of the relationship between HSR systems and tourism markets highlight the role HSR services can play in boosting tourism whenever it is able to affect the behaviour of tourists, in terms of chosen means of transport and the length of stay, and their 
choice of the destination. This is not simply a question of making cities more accessible, but it also results in the improving of their image while enhancing the coordination with and within the destination (Delaplace et al. 2014a). The issue of image enhancement is extensively discussed in the literature (Bazin et al. 2011), and it is seen as a factor from which tourism can benefit. HSR services can improve the attractiveness of a city's image by promoting its identity and, thereby, by enabling it to develop its tourist attractions. This characteristic, described as semiotic, is a positive factor both for the stakeholders of the served territories and for tourism. As a clothing brand adds value to a suit, equally the HSR services provide benefit to the served areas (Delaplace et al. 2014a). However, communication policies are obviously more limited in small towns and the effects of distinctiveness diminish over time due to an increasingly dense network of served routes and cities. This image effect is also associated with a "club" policy for the served cities in France, which is not only symbolic: "In these clubs join many public stakeholders at different scales (cities, provinces or regions), as well as private ones. Although it is difficult to measure this image effect, some trends are evident. In Reims, for example, recently, if tourists coming from the Ile de France region continue to increase, the data collected from the tourist office at the station show that the share of tourists travelling by TGV has decreased. Thus, the destination Reims is now one of the possible destinations, among the cities served by TGV service, worthy of a communication policy to encourage the renewal of the cultural supply" (Delaplace et al. 2014a: 8).

The development of tourism is also influenced by the collective strategies of local stakeholders, including the railway operator, promoters of business tourism, public-private actors or non-profit organizations operating in the entertainment and culture sectors, and local residents. Access to an HSR service can also help bring about the coordination of many local actors in the tourism sector to create an agreed image of a particular location. In this way, various actors such as a city's economic development agency or a regional tourist office might be encouraged to work together to define and promote the destination's tourist potential rather than to blur it through conflicting information or images. Tourist packages might also be developed including HSR services providing access to the location concerned or, alternatively developing procedures to enable tourists to create their own "basket of territorialized goods and services" (Pecqueur 2003). Packages can also be constructed to encourage visitors to stay overnight by including a range of cultural experiences.

In Spain, a recent study from the economic perspective (Albalate and Fageda 2016), points out that the main impact of HSR on mobility is to substitute airline passenger volumes, rather than to induce a higher number of new trips, a result countering the findings of other investigations (Castillo-Manzano et al. 2015). The analysis has been conducted at the provincial level using an econometric strategy based on the implementation of the differences-in-differences panel data method. They evaluate how HSR impacts on two tourism outcome variables: the total number of tourists (visitors) and the mean duration of their stays (number of overnights). They draw on tourism data provided by Spain's National Statistics Institute (INE) that covers 50 provinces with a 15-year time span (1998-2013). Hence, they have a sample with 750 observations. The method chosen is a slight extension of the differences-in-differences estimation procedure specified as a two-way fixed effects model: "The differences-indifferences method assumes that a counterfactual is estimated by considering the change in the outcome variable for the control group and the expected change recorded by the treated group if treatment had not occurred. However, for this assumption to be valid it is necessary to demonstrate that the temporal effect in the two groups of provinces (treated and controls) is the same in the absence of HSR" (Albalate and Fageda 2016: 180).

Two policy variables are employed that consequently produce different specifications and evaluation outcomes. First, the impact of HSR is evaluated using a binary variable that takes a value of 1 if HSR is available in the province and 0 otherwise. Second, a discrete variable is used to identify the number of HSR destinations available from any given HSR node. Beyond 
these policy variables, several groups of explanatory variables are controlled for here. First, there are considered time varying provincial characteristics that can affect the growth of tourism. Thus, the province size is introduced by including the total number of inhabitants (population), given that the total number of tourists is the dependent variable. Moreover, changes in the weather over time are controlled for by including the annual precipitation (rainfall) and the changes in the economic cycle are taken into consideration by including the unemployment rate of the province. They also include as explanatory variable the traffic moved by the airports of the province, as well as several variables related with the dynamics of the air transport market in Spain: a binary variable that takes value 1 for hub airports and the number of operating basis of low-cost airlines. Finally, we include a binary variable that takes the value 1 when a new terminal is working. This variable accounts for the capacity expansion (Albalate and Fageda 2016).

The results provide mixed evidence about the impact of HSR accessibility on tourist outcomes. On the one hand, they find that air traffic is negatively affected by HSR and air traffic is a strong predictor of tourist arrivals. This suggests a negative indirect effect of HSR on tourist outcomes (Albalate and Fageda 2016: 174). On the other hand, HSR may have a positive (weak) direct effect on tourism. However, such result is conditioned by the used measure of HSR accessibility and econometric technique. Thus, the net effect of HSR on tourism outcomes is not consistently positive. In any case, as some scholars argue, the analysis is not very convincing as there seem to be many mediating processes going on: the existence of budget airlines and their prices relative to HSR, quality of road access, proximity to major tourist attractions, quality and quantity of tourist attractions at the destinations, seasonal issues, adjacency to international tourist attractions and many others.

In their concluding remarks, Albalate and Fageda (2016) emphasize that HSR has failed to promote tourism in the areas (provinces) receiving new HSR lines. HSR seems to have a detrimental impact on air traffic so that HSR is more competitive than air travel. Still, HSR may be more competitive in terms of frequencies, travel time and comfort and not necessarily in terms of price. Given that travellers for tourism are more sensitive to price than to time, the overall competitiveness of HSR in relation to aviation may not have a positive effect on tourist outcomes (Albalate and Fageda 2016: 183). However, this general conclusion should be qualified, since business tourism practiced by professionals and high-income socio-economic categories is relatively sensitive to price but very highly sensitive to the quality and speed of service. In addition, early HSR ticket offers and promotions turn certain cities, with a good cultural offer and tourist promotion, into very competitive destinations for short-term stays (weekends and long weekends) throughout the year.

With regard to the scale of research, as other scholars have highlighted (Delaplace 2012b), the city size appears to be an important determinant of the impact of HSR on tourism, while data at the provincial level does not provide accurate information about what happens to other different urban scales. Some surveys have been made in big cities and theme Parks but very little progress has been made across the city size spectrum. In fact, it must be recognized that the whole study area is embroiled in uncertainty of cause and effect when it comes to travel access and tourism. Thus, we need to obtain more information concerning medium sized cities in different countries.

\section{Methodology}

The results reported in this article are the product of a broader research project, which has focused on the analysis of HSR in Spain and its impact on urban transformation patterns and associated local development strategies. Two of the main goals of the project are:

1. The design of a systematic study methodology of possible urban transformations (socio- 
economic and functional) raised by the implementation and commissioning of HSR services in medium and small cities.

2. The analysis and cataloguing of actions and urban strategies that have been implemented in medium-sized and small Spanish cities to seize the opportunities offered by HSR.

Also related with this second objective, we focused on the issue of potential tourism impacts associated with the opening of new HSR lines and stations. In any case, and for the purpose of this article it has not been our intention to collect data and analyse all HSR lines in a large and tourist country as Spain. Far from this goal, we have followed the line of research of other authors who have concentrated their efforts in the study of the impacts of HSR in cities located at short or medium distance from big cities and for which the travel time from the big metropolitan area does not exceed one and a half hours. Just as an example, we will mention two contributions. Bazin et al. (2013) restricted their analysis to the TGV effect in tourist destinations reachable in a less than 1.5-hour trip to/from Paris. Pagliara et al. (2015) study the impact of HSR in Madrid on tourist destination choice by means of a revealed preference survey. Results indicate that the presence of HSR does not seem to be a key factor influencing the destination choice of tourists because most of them are international tourists that can only arrive by air transportation. However, the use of HSR appears to be attractive to international tourists to visit nearby locations only.

Our study contributes to this literature by estimating empirically the impact of HSR on local tourism using a sample of municipalities surrounding the national capital, the Madrid metropolitan area. The sample of selected municipalities (Table 2) is based on several criteria: all of them are provincial capitals located in the country's inland at a distance from Madrid ranging from 72 to 300 kilometres. Likewise, all of them can be classified as intermediate cities, both by the number of inhabitants and by the role and functions that the cities play in their immediate territory, the influence and relations they exert and maintain in it and the flows and relations they generate towards the outside. Five are connected by HSR lines and stations with travel times not exceeding an hour and a half. Three out of these five cities are classified by UNESCO as world heritage, while the other two have a lower profile as tourist attractions. To the initial sample of five cities, we add three others that lack HSR connection but which are also declared by UNESCO as World Heritage Cities and are located at a distance from Madrid that turns them into tourist destinations for weekend or short stays. This sample gives us the

Medium-distance HSR services from Madrid and travel time for different modes

Table 2

\begin{tabular}{|c|c|c|c|c|c|c|c|}
\hline & \multirow{2}{*}{$\begin{array}{l}\text { Opening } \\
\text { of HSR } \\
\text { station }\end{array}$} & \multirow[t]{2}{*}{$\begin{array}{c}\text { Population } \\
(2015)\end{array}$} & \multirow{2}{*}{$\begin{array}{l}\text { Distance } \\
\text { from } \\
\text { Madrid } \\
(\mathrm{km})\end{array}$} & \multicolumn{4}{|c|}{$\begin{array}{l}\text { Travel time from Madrid } \\
\text { (minutes) }\end{array}$} \\
\hline & & & & HSR & Car & Bus & $\begin{array}{l}\text { Conven- } \\
\text { tional train }\end{array}$ \\
\hline \multicolumn{8}{|c|}{ Cities with HSR stations } \\
\hline Toledo & 2005 & 83226 & 72 & 33 & 65 & 55 & \\
\hline Segovia & 2007 & 52728 & 93 & 27 & 85 & 75 & 113 \\
\hline Valladolid & 2007 & 303905 & 196 & 65 & 145 & 135 & 178 \\
\hline Cuenca & 2010 & 55428 & 168 & 55 & 105 & 120 & 188 \\
\hline Albacete & 2010 & 172121 & 257 & 91 & 150 & 165 & 143 \\
\hline \multicolumn{8}{|c|}{ Cities without HSR stations } \\
\hline Ávila & & 58358 & 116 & & 90 & 80 & 100 \\
\hline Salamanca & & 146438 & 221 & & 147 & 165 & 170 \\
\hline Cáceres & & 95617 & 301 & & 180 & 235 & 236 \\
\hline
\end{tabular}

Source: National Statistical Institute and RENFE 
opportunity to compare cities with and without HSR, and therefore offers us the opportunity to separate the HSR effects from other factors.

After the first analysis on the evolution of travellers and overnight stays in hotel establishments for the sample of eight cities, we will focus on two exploratory case studies: Cuenca and Toledo. Moreover, why precisely these two cities? Because they represent two contrasting models of evolution and tourist dynamism despite the fact that both are served by HSR. An average, or typical case, is often not the richest in information. In clarifying lines of history and causation, it is more useful to select subjects that offer an interesting, unusual or particularly revealing set of circumstances

The methodology was both quantitative and qualitative, and focused on the collection and analysis of statistical data series. The Tourist Accommodation Occupancy Survey, conducted by the National Statistical Institute (travellers in hotel establishments; travellers in hotel establishments by nationality; average stay of travellers in tourist accommodation establishments; overnight stays by travellers) and the Hotel Accommodation Official guide produced by Turespaña. The Tourist Accommodation Occupancy Survey measures the evolution of supply and occupancy in hotel accommodation through the analysis of different variables: travellers, overnight stays, occupancy rate, number of establishments, average stay, etc. The collection of the information is carried out during seven consecutive days of each month chosen randomly, so that between all the establishments the complete month is covered. The data from this survey provide information at different scales: regional, provincial and "tourism interest points", municipalities with tourism relevance as defined by the Spanish National Statistical Office attending to their tourism supply facilities.

We have also collected information about schedules, frequencies and prices for HSR services in each of the two stations analysed. This quantitative approach has been supplemented by additional data and information obtained from interviews with some of the key local actors (managers from Tourist Offices and Convention Bureau and members of local Hospitality Business Associations); as well as a compilation of information obtained from the local and national press.

However, our research presents some methodological limitations regarding the used sources. Several cities included in the sample (Segovia, Toledo, Cuenca) receive an important volume of excursionists who can use the HSR but do not spend the night in tourist destinations. The travel times of less than one hour from Madrid and their status of heritage cities make them habitual destinations for both foreign tourists arriving in Madrid and Spanish tourists who travel from the state capital. The available sources to study the effect of HSR on excursionists (modal shifts and induced traffic) are varied but incomplete: data from tourist offices, entrance to certain monuments or museums, etc. In any case, they are not very reliable, comparable and do not cover the same registration periods across the two locations studied. Undoubtedly, the investigation and study of this type of sources would also benefit from surveys conducted among a representative sample of excursionists.

Finally, we cannot fail to mention two important facts. On the one hand, there is the disturbing factor of the economic crisis that Spain has suffered since 2008, a crisis from which tourism has begun to recover starting with 2013. To what extent the crisis has affected more or less the sample of cultural/urban tourist destinations and its varied resilience is an aspect that we must also take into account. On the other hand, the opening dates of the HSR lines differ for cities chosen between two and five years. If we take into account the time necessary to verify the effect of HSR on the sustained increase in tourism, the temporal gap may have implications that we should assess. 


\section{Results and Discussion}

\section{Cultural and urban tourism in the context of the Spanish tourist model}

Spain welcomed more than 68 million international tourists in 2015. On the other hand, the internal tourism registered in the same year more than 160 million trips made by tourists residing in the country. Spain has focused its activity on the great flows of "mass tourism", with a strong concentration of supply on the coast. Thus, the vast majority of Spanish tourist destinations offer mainly the sun and sand product, with high doses of standardization according to the predominant demand profile, which has contributed to the reduction of their profit margin in recent years. The high quality and attractiveness of tourist resources, together with the extent of its infrastructures and facilities, have made the Spanish destinations of sun and sand the benchmark for the holidays of the middle-class Europeans. The success of this model meant its systematic replication throughout the Mediterranean coast and the islands, which has involved a high level of demand concentration, both spatially and temporally. With the exception of the Canary Islands, the seasonality curve has remained practically constant in the last ten years, both in international and national tourism. Tourist flows to Spain continue to be concentrated in summer (June-September), despite their sharp growth in the remainder of the year. Because of the concentration, some of the most emblematic destinations of the Spanish coast are in the stage of maturity.

Spain has established itself as one of the main tourist destinations in the world. More than $50 \%$ of the foreign tourism received throughout 2015 came from the United Kingdom, Germany and France. Travellers from the United States and South Korea increased by $23 \%$ and $86 \%$, respectively. In fact, only tourists from Russia, Venezuela, the Philippines, and to a much lesser extent $(1.21 \%)$ from Germany declined in 2015 . By continent, $86.1 \%$ of tourists came from Europe, $7.1 \%$ from America, and the remaining $6.8 \%$ from the rest of the world.

The offer of Spanish tourist products is very varied and it is characterized by providing different types of tourist services that are partially adjusted to the new behaviours of the market. The sun and sand product remains the indisputable engine of Spanish tourism, although affected by a high level of maturity. The cultural and city tourism is a reality within the broad set of tourist products in Spain and it offers a high potential of competitive growth that should be based on a greater segmentation and specialization of the destinations. The rest of products - such as business and convention, health and wellness, sport, or rural and ecotourism - are at the development stage.

Spain offers a large number of cultural attractions and it ranks second globally in terms of UNESCO World Heritage Sites, including 13 cities and 41 monuments. Approximately $10 \%$ of tourists arriving in Spain are culturally motivated and, given that the stock of cultural products consolidates annually, this segment of the tourist market has the potential to develop further in the future. The progressive increase of tourists in the 40-60 years' age segment across Europe will also likely drive significant growth in demand for cultural and city tourism over the short to medium term. Likewise, greater accessibility to destinations, due to the expected expansion of air and intermodal transport, will mean that more and more cities and cultural tourism destinations will develop tourist initiatives introducing further competition into the market. The consequences in terms of urban and territorial policies are complex, as this type of tourism links up with the revitalisation of city centres and the development of infrastructures and events. Cultural and city tourist are typically characterised by a low seasonality and participation in such complementary activities as gastronomic consumption and shopping among others. Consequently, this market segment's higher daily expenditures make its development a leading future priority right now (Deloitte 2016). 


\section{Tourism Models in Cuenca and Toledo}

As explained earlier, we selected two case studies to investigate in depth the impacts of HSR systems on tourism and our results are presented here. Both Toledo and Cuenca are intermediate cities, albeit at the lower end of the population spectrum. They are both provincial capitals located in the Castile-La Mancha region and they are UNESCO World Heritage Sites. Toledo is a medium size town of 83226 inhabitants (2015), located in the centre of the Iberian Peninsula, some $72 \mathrm{~km}$ south of Madrid, and it was declared a World Heritage Site in 1986 for its extensive cultural and monumental heritage. Toledo was one of the former capitals of the Spanish court and a place where Christian, Jewish and Moorish cultures coexisted. Cuenca is another medium size town of 55428 inhabitants (2015), located $168 \mathrm{~km}$ east of Madrid and almost halfway between there and Valencia, located $218 \mathrm{~km}$ further to the east. It was also declared a World Heritage Site in 1996 for its extensive cultural and monumental heritage and its integration with the outstanding natural environment. Much of the old town overlooks gorges etched by the Júcar and Huécar rivers, providing a landscape of great value.

Its proximity to Madrid makes Toledo an urban-cultural destination for a large number of day-trippers. Visits of short duration often entail cursory contact with the city's heritage, limited to walking around its core and visits to the main monumental landmarks. Language tourism is an emerging market segment, linked to the supply of Spanish courses for foreigners at the University of Castile-La Mancha and the Centre for International Studies San Juan de la Penitencia, under the Ortega y Gasset Trust. In recent years Toledo has also been focusing on business tourism, including conferences, conventions, and seminars, taking advantage of several conditions: its proximity to Madrid; the power of its historical legacy; its role as regional capital; and the provision of a wide and growing range of facilities and services such as the Toledo Convention Bureau and the Toledo Conference City Trust (Cortés Alonso 2002). Toledo enjoys a privileged position in the Spanish tourism context. It is one of the most popular heritage destinations and it hosts approximately 1.5 to 1.7 million tourists a year (Troitiño Vinuesa and Troitiño Torralba 2009), most of whom spend a day or a few hours in the city. Although dominated by domestic visitors, Toledo's national prominence as a destination for cultural tourism attracts greater presence of foreign visitors than many other locations including Cuenca (Table 3).

Table 3

\section{Percentage of travellers in hotel establishments between 2005 and 2015, by nationality}

\begin{tabular}{|c|c|c|c|c|}
\hline \multirow[t]{2}{*}{ Year } & \multicolumn{2}{|c|}{ Cuenca } & \multicolumn{2}{|c|}{ Toledo } \\
\hline & $\begin{array}{c}\text { Domestic } \\
\text { tourists }\end{array}$ & $\begin{array}{l}\text { Foreign } \\
\text { tourists }\end{array}$ & $\begin{array}{l}\text { Domestic } \\
\text { tourists }\end{array}$ & $\begin{array}{l}\text { Foreign } \\
\text { tourists }\end{array}$ \\
\hline 2005 & 90.8 & 9.2 & 72.5 & 27.5 \\
\hline 2006 & 89.6 & 10.4 & 70.8 & 29.2 \\
\hline 2007 & 86.9 & 13.1 & 71.6 & 28.4 \\
\hline 2008 & 87.3 & 12.7 & 71.1 & 28.9 \\
\hline 2009 & 84.4 & 15.6 & 72.8 & 27.2 \\
\hline 2010 & 82.4 & 17.6 & 70.7 & 29.3 \\
\hline 2011 & 83.1 & 16.9 & 67.8 & 32.2 \\
\hline 2012 & 81.5 & 18.5 & 67.3 & 32.7 \\
\hline 2013 & 84.3 & 15.7 & 68.2 & 31.8 \\
\hline 2014 & 87.2 & 12.8 & 70.6 & 29.4 \\
\hline 2015 & 87.6 & 12.4 & 68.6 & 31.4 \\
\hline
\end{tabular}

Source: Tourist Accommodation Occupancy Survey, National Statistical Institute 
Cuenca is a highly ranked tourist and excursion destination with further development potential and it already attracts about 800000 visitors annually, for both leisure and cultural activities. Visiting monuments and historic sites ranked first, followed by the objective of enjoying nature. Given that Cuenca has a special harmony between nature and architecture, it is usual to combine the visit to the historic old town with a journey through some of the protected natural areas located in the same municipality. However official statistics show that the number of tourists visiting Toledo is more than double those visiting Cuenca. In recent years, the gap has even increased, with visits to Toledo rising - especially in 2014 with the Greco Year, while those to Cuenca have slowed noticeably. Of the estimated 3.5 million tourists who visited Toledo in 2014, 810990 stayed at least one night in a local hotel, which is 57.7 percent higher than overnight stays for one day in Cuenca. On the other hand, the average length of stay per visitor in Cuenca is usually somewhat higher, with 1.6 days per person compared to 1.5 days in Toledo (Table 4). In any case, Toledo is a mature tourist destination with international recognition and visibility while Cuenca lacks the notoriety that it deserves for its heritage resources. The gap between the two is very large and Cuenca will still have to work hard on the creation of tourism products and on the elaboration of a tourism marketing plan agreed upon and supported by all stakeholders.

\section{Average length of stay of tourists between 2005 and 2015 (in days)}

Table 4

\begin{tabular}{|r|r|r|r|}
\hline Year & Cuenca & Toledo & Castile-La Mancha region \\
\hline $\mathbf{2 0 0 5}$ & 1.60 & 1.56 & 1.73 \\
\hline $\mathbf{2 0 0 6}$ & 1.60 & 1.62 & 1.73 \\
\hline $\mathbf{2 0 0 7}$ & 1.65 & 1.60 & 1.76 \\
\hline $\mathbf{2 0 0 8}$ & 1.67 & 1.62 & 1.80 \\
\hline $\mathbf{2 0 0 9}$ & 1.68 & 1.57 & 1.78 \\
\hline $\mathbf{2 0 1 0}$ & 1.62 & 1.56 & 1.76 \\
\hline $\mathbf{2 0 1 1}$ & 1.56 & 1.55 & 1.75 \\
\hline $\mathbf{2 0 1 2}$ & 1.51 & 1.49 & 1.68 \\
\hline $\mathbf{2 0 1 3}$ & 1.57 & 1.51 & 1.68 \\
\hline $\mathbf{2 0 1 4}$ & 1.65 & 1.51 & 1.65 \\
\hline $\mathbf{2 0 1 5}$ & 1.65 & 1.50 & 1.66 \\
\hline
\end{tabular}

Source: Tourist Accommodation Occupancy Survey, National Statistical Institute

\section{Improving accessibility and expectations associated with HSR in terms of tourism development: disappointed expectations and ambivalent impacts}

In Toledo, the old train station, which dates from 1919 and it is located at the edge of the city, has been restored to cater for the HSR trains and the old conventional line has been dismantled. Before the HSR construction began in 2002, rail traffic between Madrid and Toledo in 2002 amounted to 874336 travellers per year. This figure rose by $30 \%$ to 1140502 in 2006, the first full operational year of the HSR rail services after its opening in November 2005, and to 1513000 in 2009. Travel times were halved from 60 to 30 minutes, and neither private cars nor interurban buses could compete in terms of travel time, particularly during Madrid's peak hours (Guirao and Soler 2008).

In the case of Cuenca, the completion of the HSR line in December 2010 did not mean the disappearance of conventional trains and dual modes persisted. Moreover, the new high-speed station (Fig. 2), was located $5 \mathrm{~km}$ from the city centre. In 2011, just over 220000 passenger trips were recorded on the HSR service - a modest beginning, but that number gradually 
increased to almost 280000 in 2013. Today, the main problem is the station's poor connectivity with Cuenca's other transport networks, which makes it difficult for it to become, in the short term, hub for local economic promotion (Ortuño-Padilla et al. 2014). Public transport access to the HSR station involves either taxis or buses, but the latter depart for the central bus station every 20 minutes and they take travellers on a circuitous route that lengthens the ride to $7 \mathrm{~km}$, and an average time of 15 minutes for the full trip (Vázquez Varela and Martínez Navarro 2015). However, a clear improvement in Cuenca's connectivity with the two main cities of the Madrid-Levante HSR line - Madrid and Valencia - cannot be denied. The travel time on conventional trains between Madrid and Cuenca was of 3.5 hours, while that between Cuenca and Valencia was a little longer. Those times have been reduced to 55 and 58 minutes respectively.
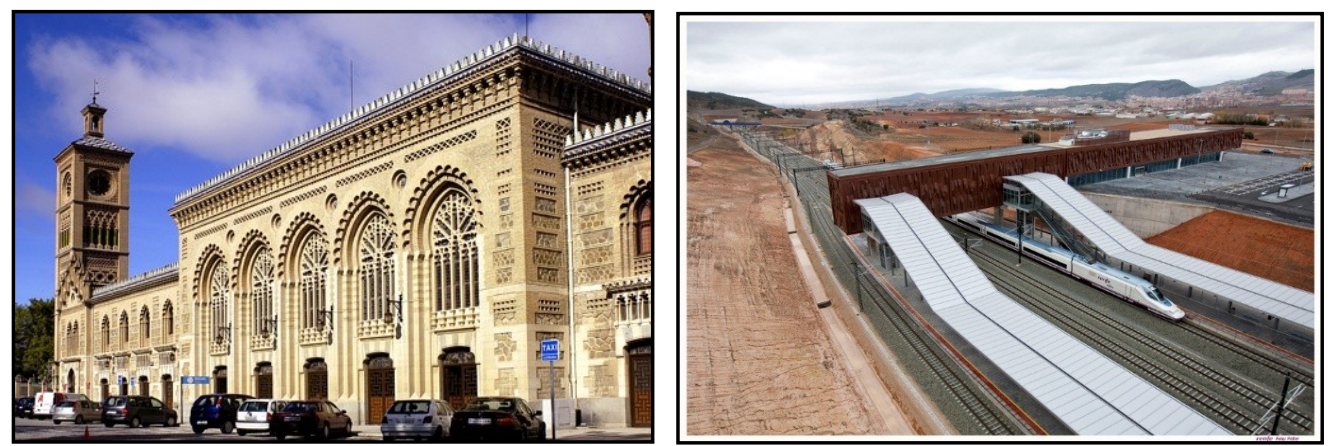

Fig. 2 - The HSR stations of Toledo (left) and Cuenca (right) Source: Adif Alta Velocidad (2016)

HSR transport services between Toledo and Madrid have encouraged daily commuting between the former and the latter, assisted by the purchase of monthly season tickets which are considerably cheaper than normal tickets which cost $12.9 €$ one-way. Also, on working days, tourists travelling in the opposite direction to Toledo help fill seats on the return journey. Thus the line accommodates 15 high-speed rail shuttles in both directions during working days and 10 at weekends. A survey conducted in 2007 revealed that from Monday to Friday $50 \%$ of trips have a work purpose, $30 \%$ are tourists and $8 \%$ students. Of the commuters with season tickets, $70 \%$ of them live in Toledo and only $20 \%$ are living in Madrid. Of the tourist trips on working days, $70 \%$ are not Spanish and usually buy their tickets in the origin train station on the same day of the trip (Guirao and Soler 2008).

The Cuenca HSR station is an intermediate one, so the line is used to connect the city with larger urban centres such as Madrid, Valencia, Seville ( 3 hours 20 minutes) and Alicante (1 hour 32 minutes). The line is provided with 28 daily HSR connections in different directions during working days and 21 on weekends. During working days, the reasons for travelling are mainly related to work, while during weekends and holiday periods the proportion of tourists increases. At present, most of the complaints about the service focus on the lack of season tickets associated with shuttle trains and schedules that do not allow early arrival in Madrid, Valencia and Albacete. However, it is possible to get great discounts in the case of early bird prices.

It is extremely difficult to quantify exactly the effect that HSR has had on the arrival of visitors and tourists to both Cuenca and Toledo. In order to search for more clear insights about this topic in other similar cities, we selected a sample of eight cities, five of them served by HSR (Toledo, Segovia, Valladolid, Cuenca and Albacete), while Ávila, Cáceres and Salamanca have no HSR access. These intermediate cities are located in the inland of the Iberian Peninsula and 
they range between 72 and 300 kilometres from Madrid. They are all tourist destinations, but six of them are UNESCO World Heritage listed cities: Toledo, Ávila, Segovia, Salamanca, Cáceres and Cuenca. Albacete and Valladolid are destinations for what one might term urban tourism. Data on travellers and overnight stays in hotels (Fig. 3, Fig. 4) provides us with eight tourist destinations whose recent evolution has been completely different.

Segovia has undergone the most favourable increase in its tourist traffic, followed by Toledo and Valladolid at some distance behind. Their HSR stations opened between 2005 (Toledo) and 2007 (Segovia and Valladolid). In this sense, the cities that get the best scores seem to confirm the thesis that the arrival of the HSR to a city seems to boost the tourist flows, although the times and the scores do not always correlate exactly. However, the three cities that follow them in scoring, Ávila, Salamanca and Cáceres, lack a high-speed railway station, which has not prevented them from showing positive trends or that Salamanca is the city with the largest number of travellers staying in hotel establishments of the entire selected sample. Finally, Albacete and Cuenca close the list of the obtained scores. They were incorporated into the high-speed network in 2010, but, despite this, they have not managed to keep pace with competitors still lacking a HSR station.

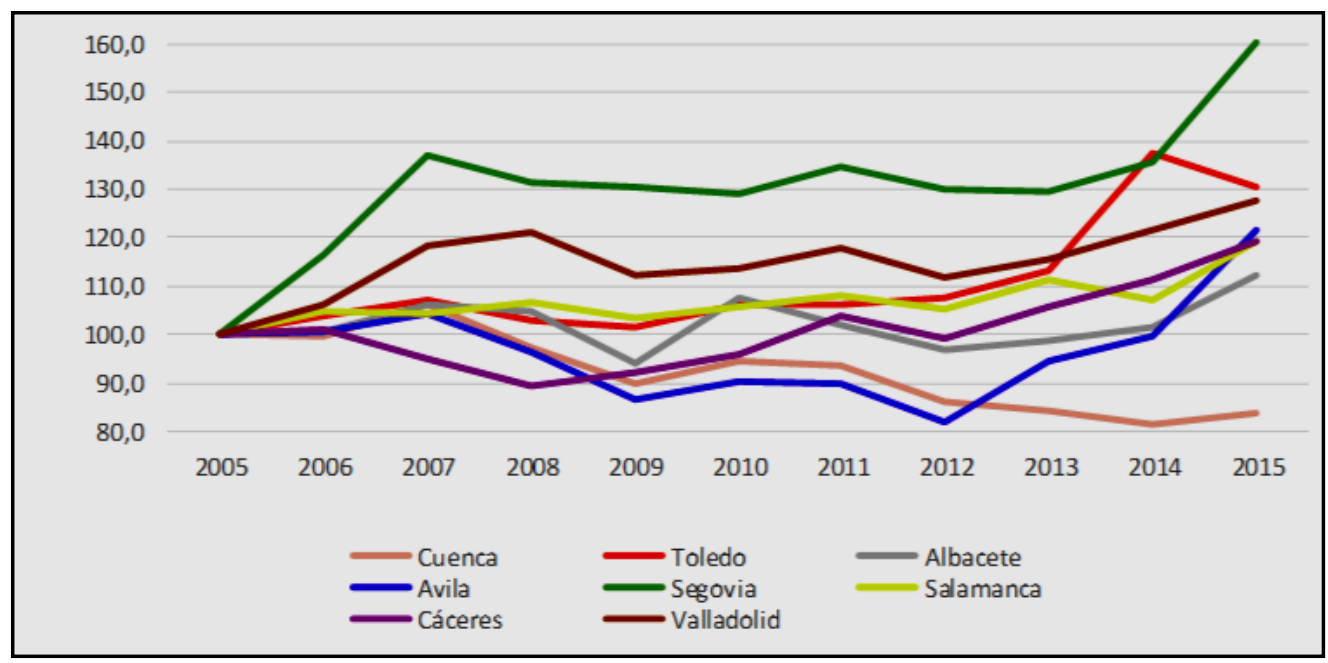

Fig. 3 - Travellers in hotel establishments between 2005-2015 (on an index base $2005=100$ ) Source: Tourist Accommodation Occupancy Survey, National Statistical Institute

If we go back to our two case studies (Table 5), Toledo recorded a steady growth in the number of travellers, with a slight decrease in the early years of the economic crisis (2008 and 2009) and a spectacular jump after 2013. In contrast, the crisis helps explain the continued decline of tourists and the overnight stays during the same period in Cuenca, a situation that the arrival of HSR failed to reverse. So the evolution of Cuenca's tourist numbers reflects the average of the region to which it belongs, a territory of markedly rural characteristics. It therefore seems clear that the development of HSR has had two quite different effects on our two case study locations. Likewise, the proximity of nearby Madrid, which is either a source of day-trippers or the starting point for numerous possible routes linking World Heritage destinations, has different effects on the two locations. 


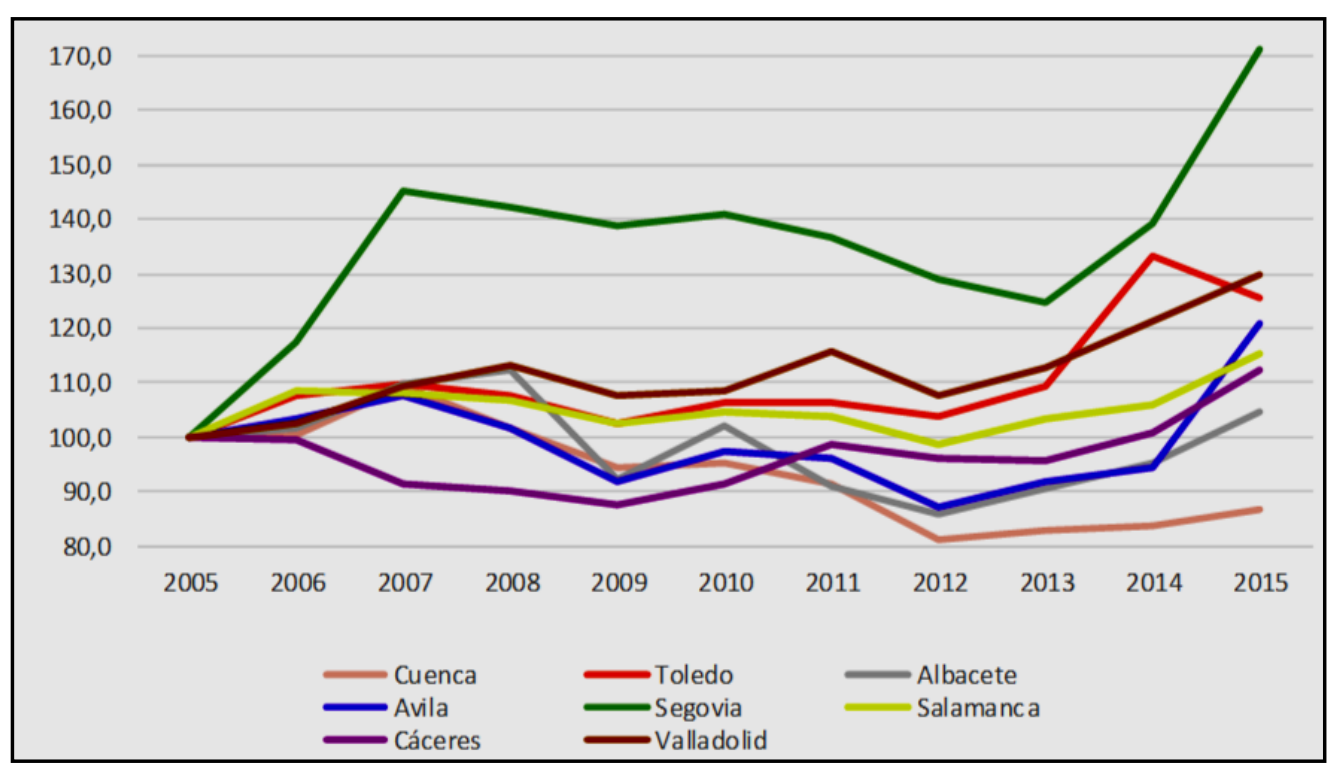

Fig. 4 - Overnight stays by travellers between 2005-2015 (on an index base $2005=100$ ) Source: Tourist Accommodation Occupancy Survey, National Statistical Institute

Table 5

Travelers in hotel establishments and overnight stays by travellers between 2003 and 2015 (absolute data)

\begin{tabular}{|c|c|c|c|c|c|c|}
\hline \multirow[t]{2}{*}{ Year } & \multicolumn{3}{|c|}{ Travellers in hotel establishments } & \multicolumn{3}{|c|}{ Overnight stays by travellers } \\
\hline & Cuenca & Toledo & $\begin{array}{l}\text { Castile-La } \\
\text { Mancha } \\
\text { region }\end{array}$ & Cuenca & Toledo & $\begin{array}{c}\text { Castile-La } \\
\text { Mancha } \\
\text { region }\end{array}$ \\
\hline 2003 & 174913 & 375985 & 1788369 & 286530 & 575804 & 3013400 \\
\hline 2004 & 203019 & 412495 & 1899183 & 327912 & 639269 & 3209495 \\
\hline 2005 & 209196 & 434615 & 1982708 & 335417 & 677065 & 3438796 \\
\hline 2006 & 208923 & 450669 & 2084181 & 335847 & 729706 & 3618422 \\
\hline 2007 & 222182 & 465418 & 2187095 & 367153 & 742054 & 3847538 \\
\hline 2008 & 203849 & 448007 & 2117135 & 340887 & 728138 & 3807440 \\
\hline 2009 & 188093 & 441644 & 1970296 & 316474 & 694483 & 3518963 \\
\hline 2010 & 197584 & 460795 & 1969158 & 318527 & 719281 & 3479503 \\
\hline 2011 & 196179 & 462063 & 1911229 & 306060 & 718745 & 3352303 \\
\hline 2012 & 179893 & 468633 & 1764436 & 272480 & 700796 & 2974774 \\
\hline 2013 & 176427 & 491362 & 1743486 & 276947 & 738586 & 2933088 \\
\hline 2014 & 170192 & 596980 & 1908864 & 281198 & 902451 & 3173960 \\
\hline 2015 & 175654 & 566977 & 1963232 & 290852 & 849132 & 3269043 \\
\hline
\end{tabular}

Source: Tourist Accommodation Occupancy Survey, National Statistical Institute

In parallel with a progressive increase in tourists, Toledo has experienced a significant growth and major renovation of its hotel infrastructure with the opening of three, four and five star 
hotels located on the edge of the historic city centre and the access routes to the city. In particular, the increase in the supply of medium and high categories has been significant (Table 6 ). On the other hand, the recovery of old manor houses and the demand from visitors for staying in "charming places" have fostered the opening of new small hotel establishments in the historical district, providing the city with a wide range and affordable supply for all kinds of travellers. It is difficult to prove whether the construction or refurbishment of hotels precedes or it follows the increase of tourists, as well as whether the construction is demonstrably affected by the arrival of HSR. The new hotels of high categories were built and opened between 2006 and 2007, while several hotels of four stars were refurbished and completed between 2006 and 2009. The dates overlap with the four years following the arrival of the high-speed train (2005), but also with the last years of the financial-real estate boom in Spain. After the outbreak of the economic crisis, and despite the fact that the number of travellers has continued to increase, the opening of new hotel establishments has stagnated so far.

\section{Evolution of hotel accommodation by category and number} of hotel beds (2003-2016)

\begin{tabular}{|c|c|c|c|c|c|}
\hline & \multirow[t]{2}{*}{ Category } & \multicolumn{2}{|c|}{ Hotel establishments } & \multicolumn{2}{|c|}{ Number of hotel beds } \\
\hline & & 2003 & 2016 & 2003 & 2016 \\
\hline \multicolumn{6}{|l|}{ CUENCA } \\
\hline & Five stars hotel & & & & \\
\hline & Four stars hotel & 3 & 5 & 509 & 737 \\
\hline & Three stars hotel & 3 & 5 & 386 & 467 \\
\hline & Two stars hotel & 3 & 3 & 162 & 141 \\
\hline & One star hotel & & & & \\
\hline & Two stars hostel & 7 & 16 & 305 & 464 \\
\hline & One star hostel & 2 & 3 & 30 & 76 \\
\hline & Guesthouse & 1 & 3 & 30 & 62 \\
\hline & Total & 19 & 35 & 1422 & 1947 \\
\hline \multicolumn{6}{|l|}{ TOLEDO } \\
\hline & Five stars hotel & & 3 & & 424 \\
\hline & Four stars hotel & 5 & 9 & 1108 & 1693 \\
\hline & Three stars hotel & 12 & 15 & 1010 & 1549 \\
\hline & Two stars hotel & 7 & 7 & 278 & 278 \\
\hline & One star hotel & 1 & 1 & 36 & 36 \\
\hline & Two stars hostel & 16 & 21 & 411 & 500 \\
\hline & One star hostel & 4 & 4 & 67 & 67 \\
\hline & Guesthouse & 2 & 1 & 19 & 7 \\
\hline & Total & 47 & 61 & 2929 & 4554 \\
\hline
\end{tabular}

Source: Hotel Accommodation Official guide and Turespaña

\section{HSR trains and tourism in Cuenca and Toledo: renewed image and coordination tool}

The contribution of HSR to both cities in terms of image enhancement is undeniable. Both cities have significantly improved their accessibility in time and quality of service, especially in the case of Cuenca, where, in addition to a reduction of more than $65 \%$ of travel time to Madrid, we can add its direct connection with 11 other HSR cities included within the network. On the other hand, this image effect has also been associated with a "club" policy under the name Avexperience offering combined packages for each destination, including train tickets plus hotel at very competitive prices. However, again in this case, it does not appear that the image 
enhancement has resulted in both cases in a growing tourist flow.

The collective strategies of the various stakeholders in both cities have shown very different levels of effectiveness. Stakeholders include railway operators, promoters of business tourism, and operators in the entertainment and cultural sectors - whether public, private or non-profit. In the past, both cities have tested new models of heritage and tourism management as evidenced by the creation of various institutions such as separate Consortia and Convention Bureaux in both Toledo and Cuenca. Both cities have produced planning documents: Cuenca Tourism Promotion Plan 1998-2001; Toledo Plan for Tourist Excellence 2000-2002; and Toledo Quality Tourist Destination Plan. However, their ability to engage all stakeholders and to arouse the support of various institutions has been different, as clearly demonstrated by the recent dissolution of the Cuenca Tourism Foundation, after 12 years of work between 2004 and 2016.

Undoubtedly, the city of Toledo has benefited from its higher profile as a tourist destination for decades. We must add to this its ability to promote the provincial capital as a business tourism destination for congresses and meetings. The new "El Greco" Convention Centre was opened in 2012. Its capacity to expand and diversify cultural and leisure activities created such new projects as the Greco year 2014, and such important exhibitions as El griego de Toledo, and El Greco y su taller: arte $y$ oficio, which had great public success. Its ability to create new tourism products and to attract more visitors is aided by the city's ability to link it with HSR, as occurred with the development of the Spanish Gastronomy Capital theme in 2016. The city has also worked with the HSR operator to design and promote travel or tour packages based, for example during the Greco year 2014, on direct connections to Barcelona, Malaga and Seville.

The city of Cuenca has its own features, which clearly differ from those of Toledo. Thus, the HSR service has improved the image of the city and its attractiveness by asserting its identity and, thereby, enabling it to develop its tourist attractions with a higher degree of visibility as a tourist destination in both national and international arenas. But the impact has been much smaller than that of Toledo. Efforts to give the city a Convention Centre have been crippled by the global financial crisis, so that attempts to promote the city as a business tourism destination are restricted by the limitations of the existing infrastructure that can only serve small business meetings, incentive trips and minor conferences. Attempts to expand and diversify the city's cultural and leisure opportunities were only implemented in 2016, much behind Toledo. This entailed developing new cultural projects that seek to break seasonality and also attract more visitors by linking their promotion with the presence of HSR. Thus an exhibition entitled $A i$ Weiwei. La poética de la libertad, which opened between July and December in the gothic cathedral of Cuenca, was packaged with HSR tickets and hotel accommodation, thereby combining the efforts of several stakeholders. Data collected from January to December seem to show an increase of $13 \%$ both in the registered number of tourists and overnight stays compared with the same period the previous year, suggesting that HSR is a necessary, but not sufficient, element in developing tourism.

\section{Conclusions}

Most scholars agree that it will take some time to understand the development effects of commissioning and implementing new infrastructure (Bellet et al. 2010, Bellet Sanfeliu 2013). A revolution in mobility practices, defined by modal shifts and induced traffic (Menéndez et al. 2016), follows immediately the deployment of these services. Nevertheless, the impact of these new practices on the socio-economic dynamics may take much longer. The French academic literature, which already has great experience on the subject, suggests that we have to wait 20 years to assess the new socio-economic dynamics and spatial impact that can be generated with the implementation of a new infrastructure such as HSR trains (Klein and Million 2005). Obviously, taken together, the time required testing the effects of HSR in the territory, coupled 
with the economic crisis that has been going on for more than eight years, have complicated the possibilities of obtaining conclusive results.

However, the HSR can become a dynamic tool where there is a strong governmental guidance and leadership at city and territory level, while stakeholders are collectively able to define strategies needed to adapt the infrastructure to enhance the tourist experiences (Bellet Sanfeliu 2013, Bellet et al. 2016). The transformation of public images of city or territory accessibility is immediate and it occurs mostly with the new infrastructure's opening. Places suddenly become more accessible and more likely to be explored. The city that hosts the new infrastructure gets more visibility and opportunities to promote itself. The HSR adds an air of modernity to the city where it operates, a collective illusion that should not be wasted (Paül i Agusti 2009), since following the changes of accessibility of the served territories, the involved actors are expecting economic dynamism in general and tourism in particular. However, the automatic nature of the effects of transport infrastructures on local economic development, commonly known as a "structuring effect", is largely a myth (Offner 1993).

The arrival of HSR certainly had immediate effects on many aspects of life and society of the two selected cities, although most diagnoses agree on the fact that tourism, accommodation and catering industries were likely to benefit most from its development. However, tourism is a multi-faceted and highly differentiated good - depending on location - and we should both broaden and deepen the research field by researching numbers of tourist visitors, the development of tourist service companies, changes in the number of conferences and meetings, changing employment in the tourism sector - including the number and types of jobs, revealed preference surveys among tourists, and so on. More accurate and conclusive data of these kinds can help each city in defining, implementing and revising their own tourism strategies.

Our Spanish study has shown that it is difficult to quantify the impact of HSR on tourism, but the opportunity to compare cities with and without HSR allows us to separate the HSR effects from other factors. In this sense, it is evident that from the mentioned sample of eight cities, the three that have grown the most in visitors have been Segovia, Toledo and Valladolid, all three with HSR station but with very different tourist resources. Segovia and Toledo are heritage cities, with a highly defined profile of cultural tourism. However, Valladolid has had to invest and bet on other complementary tourism products such as wine tourism, gastronomy and cultural events and congresses. The three cities that score in the middle area of the table Ávila, Salamanca and Cáceres also correspond to the profile of heritage cities, whose tourist resources are important enough and have sufficient visibility to increase the flows of visitors despite lacking connection to the HSR network. Finally, Albacete and Cuenca, with the worst data of growth in terms of visitors housed in hotel establishments, joined the HSR network somewhat later and with very different profiles and resources. At least partial confirmation for our conclusions is to be found in the findings of other investigations. Albalate (2015) argue that the number of tourists grew faster in recent years in destinations (Spanish provinces) not connected to the HSR network than in destinations connected to it, indicating that factors other than the availability of this service may have significant influence on tourist attraction. Among intermediate cities, only those pre-equipped with good tourist amenities enjoyed significant impacts.

Another aspect that should have an impact on tourist flows, which is repeatedly assessed in the academic literature, concerns HSR stations located peripherally to cities. Many scholars argue that peripheral HSR stations tend to give poorer results in terms of traffic and services. However, this condition has had little effect on a major tourist destination like Segovia where the high-speed station is $6 \mathrm{~km}$ far from the city centre and the evolution of tourist flows, despite the slight decrease during the hardest years of the economic crisis, has been especially 
positive. This view is substantiated to some extent by Cuenca, whose high-speed station is 5 $\mathrm{km}$ away from the city centre. Its fall in the number of visitors during the years of the financial crisis and the modest recovery in numbers since 2014 cannot be due exclusively to the location of the HSR infrastructure.

Another conclusion from this study of the relationship between tourism and HSR in World Heritage Cities, especially Toledo and Cuenca, is that their experiences differ considerably, and they demand the understanding of their contexts (Delaplace et al. 2014a). HSR and its effects cannot be understood independently of the socio-economic and territorial characteristics of the served areas, whether we focus on tourism or other industries (Delaplace et al. 2014a). Once again, we're back to complexity, circularity, uncertainty and so on. The analysis of the available experience shows that the availability of HSR gives value to already known and popular tourist destinations but it is not sufficient on itself to promote further development (Albalate et al. 2015). In short, infrastructures are necessary but not sufficient for socioeconomic development, specifically tourism, and their effectiveness depends on a many accompanying conditions. Elapsed time since the opening of an HSR station may also be a differentiating factor on a place's capacity to attract tourists. Toledo's HSR station opened in 2005 and Cuenca's in 2010. Another factor affecting outcomes is the capacity of local actors to work collectively to develop, fund and implement strategies to improve tourist products. And 'intermediate cities' of the kinds discussed here have to confront the reality of increased spatial competition for visitors, regionally, nationally and internationally due to improved transport access.

The HSR contributes towards putting the city on the tourist map and it increases the tourist awareness of the destination. As a result, urban tourism could register a significant increase. Nevertheless, this growth is not only related to the HSR and to hospitality infrastructure development; it is also the result of the capacity for coordination and organization followed by an aggressive promotion and communication strategy.

\section{Acknowledgments}

This article is part of the dissemination of the outcome of a Research project financed by the Spanish Ministerio de Economía y Competitividad - Subdirección General de Proyectos de Investigación: Patrones de transformación urbana y estrategias asociadas a la alta velocidad ferroviaria en España (URBATAV) - CSO2012-34629. We are very grateful to the editors and the reviewers for their help in revising the text and for their advice concerning the preparation of the final version of the paper. The manuscript has been substantially improved and modified based on their inspiring suggestions.

\section{References}

ALBALATE D. (2015), Evaluating HSR access on tourism: evidence from Spanish provinces and cities, ERSA conference papers, 1-22.

ALBALATE D., BEL G. (2012), High-Speed Rail: Lessons for Policy Makers from Experiences Abroad, Public Administration Review 72 (3), 336-349.

ALBALATE D., BEL G. (2015), La experiencia internacional en alta velocidad ferroviaria, FEDEA, Retrieved from: http://documentos.fedea.net.

ALBALATE D., CAMPOS J., JIMÉNEZ J. L. (2015), Tourism and high speed rail in Spain: Does the AVE increase local visitors? Research Institute of Applied Economics, Retrieved from: www.ub.edu/irea/.

ALBALATE D., FAGEDA X. (2016), High speed rail and tourism: Empirical evidence from Spain, Transportation Research Part A: Policy and Practice 85, 174-185.

BAZIN S., BECKERICH C., BLANQUART C., DELAPLACE M., VANDENBOSSCHE L. 
(2011), Grande vitesse ferroviaire et développement économique local: une revue de la littérature, Recherche Transports Sécurité 27 (3), 215.

BAZIN S., BECKERICH C., DELAPLACE M. (2013), Desserte TGV et villes petites et moyennes, Une illustration par le cas du tourisme à Arras, Auray, Charleville-Mézières et Saverne, Les Cahiers Scientifiques du Transport 63, 33-62.

BEL G. (2011), Infrastructure and nation building: the regulation and financing of network transportation infrastructures in Spain (1720-2010), Business History 53 (5), 688-705.

BELLET C. (2016), Peripheral High-Speed Rail Stations in Spain, The Open Transportation Journal 10 (Suppl-1, M5), 45-56.

BELLET C., ALONSO P., CASELLAS A. (2010), Infraestructuras de transporte y territorio. Los efectos estructurantes de la llegada del tren de alta velocidad en España, Boletín de la Asociación de Geógrafos Españoles 52, 143-163.

BELLET C., ALONSO P., GUTIÉRREZ A. (2016), The high-speed rail in Spanish cities: Urban integration and local strategies for socio-economic development, in: de Ureña J. M. (ed.), Territorial implications of high speed rail. A Spanish perspective, Routledge, London and New York, pp. 163-196.

BELLET SANFELIU C. (2013), Transporte y desarrollo territorial. El estudio de los efectos asociados a la implantación del alta velocidad ferroviaria a través del caso español, Revista Transporte y Territorio 8, 117-137.

BELLET SANFELIU C., JURADO ROTA J. (2014), La localización de las estaciones de Alta Velocidad en España, Anales de geografía de la Universidad Complutense 34 (2), 9-24.

BERGER R. (2015), European city tourism 2015. Study - Analysis and findings, Retrieved from: https://www.rolandberger.com.

BERION P., JOIGNAUX G., LANGUMIER J.-F. (2007), L'évaluation socio-économique des infrastructures de transport : enrichir les approches du développement territorial, Revue d'Economie Régionale \& Urbaine 4, 651-676.

BERTOLINI L. (1996), Nodes and places: complexities of railway station redevelopment, European Planning Studies 4 (3), 331-345.

BRONS M., GIVONI M., RIETVELD P. (2009), Access to railway stations and its potential in increasing rail use, Transportation Research Part A: Policy and Practice 43 (2), 136 -149 .

CASTILLO-MANZANO J. I., POZO-BARAJAS R., TRAPERO J. R. (2015), Measuring the substitution effects between High Speed Rail and air transport in Spain, Journal of Transport Geography 43, 59-65.

CHENG Y.-H. (2010), High-speed rail in Taiwan: New experience and issues for future development, Transport Policy 17 (2), 51-63.

CHEN Z., HAYNES K. (2012), Tourism Industry and High Speed Rail, Is There a Linkage: Evidence from China's High Speed Rail Development, George Mason University, Retrieved from: https://papers.ssrn.com.

CORTÉS ALONSO F. (2002), La Fundación "Toledo, Ciudad de Congresos", in: Campos Romero M. L. (ed.), El turismo en Castilla-La Mancha: análisis y prospectiva, Cuenca, Universidad de Castilla-La Mancha, pp. 133-142.

DELAPLACE M. (2012a), Pourquoi les " effets " TGV sont-ils différents selon les territoires? L'hétérogénéité au coeur du triptyque "Innovations, Territoires, Stratégies », Recherche Transports Sécurité 28 (3), 290-302.

DELAPLACE M. (2012b), TGV, développement local et taille des villes : Une analyse en termes d'innovation de services, Revue d'économie régionale \& urbaine 2, 265-290.

DELAPLACE M., BAZIN S., PAGLIARA F., SPOSARO A. (2014a), High speed railway system and the tourism market: between accessibility, image and coordination tool, $54^{\text {th }}$ European Regional Science Association Congress, Retrieved from: https://halshs.archivesouvertes.fr.

DELAPLACE M., PAGLIARA F., PERRIN J., MERMET S. (2014b), Can high speed rail foster the choice of destination for tourism purpose? Procedia - Social and Behavioral Sciences 
$111,166-175$.

DELOITTE (2016), Expectativas 2016. Playing to win. Travel, Hospitality, Leisure \& Transport, Retrieved from: https://www2.deloitte.com.

FACCHINETTI-MANNONE V., BAVOUX J.-J. (2010), L'implantation des gares TGV en

France : tensions interscalaires, jeux d'acteurs et recompositions spatiales, Belgeo 1-2, 9-22.

FACCHINETTI-MANNONE V., BELLET C., RIBALAYGUA C., RICHER C. (2013), Les

petites agglomérations françaises et espagnoles face à la grande vitesse ferroviaire : comment convertir l'accessibilité en attractivité ? les Cahiers Scientifiques du Transport 63, 3-31.

HALL P. (2009), Magic Carpets and Seamless Webs: Opportunities and Constraints for High-Speed Trains in Europe, Built Environment 35 (1), 59-69.

GARMENDIA M., RIBALAYGUA C., UREÑA J. M. (2012), High speed rail: implication for cities, Cities 29 (Suppl. 2), S26-S31.

GIL ÁLVAREZ E. (2010), Caracterización del turismo e incidencia potencial y real de la implantación de la alta velocidad en Segovia, Lurralde: investigación y espacio 33, 119-145.

GIVONI M., BANISTER D. (2012), Speed: the less important element of the High-Speed Train, Journal of Transport Geography 22, 306-307.

GUIRAO ABAD B. (2000), El cálculo del tráfico inducido como herramienta en la planificación de las infraestructuras de transporte. Aplicación a la puesta en servicio de las nuevas líneas ferroviarias de alta velocidad en España, Unpublished PhD thesis, Universidad Politécnica de Madrid, Retrieved from: http://oa.upm.es.

GUIRAO B., SOLER F. (2008), Impacts of the new high speed rail services on small tourist cities: the case of Toledo (Spain), WIT Transactions on Ecology and the Environment 117, 465-473.

KLEIN O., MILLION F. (2005), La grande vitesse ferroviaire, le développement socioéconomique et l'aménagement des territoires : étude bibliographique et analyse des expériences passées, Direction Départementale de l'Equipement de la Charente, Retrieved from: http://www.charente.gouv.fr.

LEVINSON D. M. (2012), Accessibility impacts of high-speed rail, Journal of Transport Geography 22, 288-291.

MASSON S., PETIOT R. (2009), Can the high speed rail reinforce tourism attractiveness? The case of the high speed rail between Perpignan (France) and Barcelona (Spain), Technovation 29 (9), 611-617.

MENÉNDEZ J. M., RIVAS A., GALLEGO I. (2016), Mobility characteristics of mediumdistance high-speed rail services, in: de Ureña J. M. (ed.), Territorial implications of HighSpeed Rail. A Spanish perspective, Routledge, London and New York, pp. 105-128.

OFFNER J.-M. (1993), Les " effets structurants » du transport : mythe politique, mystification scientifique, L'espace géographique 22 (3), 233-242.

ORTUÑO-PADILLA A., BAUTISTA-RODRIGUEZ D., FERNÁNDEZ-ARACIL P., LIBOUREL E. (2014), High-speed train territorial impact in French and Spanish medium cities with stations located in the outskirts, Transport Research Arena, Retrieved from: https:// hal-enpc.archives-ouvertes.fr.

PAGLIARA F., LA PIETRA A., GÓMEZ J., VASSALLO J. M. (2015), High speed rail and the tourism market: Evidence from the Madrid case study, Transport Policy 37, 187-194.

PAGLIARA F., VALERI E., DE ABREU E SILVA J. (2013), Is there an impact of high speed rail on tourism? $13^{\text {th }}$ WCTR, Retrieved from: http://www.wctrs-society.com.

PAÜL I AGUSTI D. (2009), El tren de alta velocidad en las estrategias de promoción urbanas, in: Caravaca Barrosso I., Fernández Salinas V., Silva Pérez R. (eds.), Ciudades, culturas y fronteras en un mundo en cambio, Junta de Andalucía, Sevilla, pp. 237-248.

PECQUEUR B. (2003), Dans quelles conditions les objets patrimoniaux peuvent-ils être support d'activité ? Montagnes Méditerranéennes 15, 123-129.

PERL A. D., GOETZ A. R. (2015), Corridors, hybrids and networks: three global development strategies for high speed rail, Journal of Transport Geography 42,134-144.

PRESTON J., WALL G. (2008), The ex-ante and ex-post economic and social impacts 
of the introduction of High Speed Trains in South East England, Planning Practice and Research 23 (3), 403-422.

PRIDEAUX B. (2000), The role of the transport system in destination development, Tourism Management 21 (1), 53-63.

SALA-I-MARTIN X. (1997), És bo que el govern inverteixi <<sempre>> a les regions menys desenvolupades? Nota d'Economia 57, 123-157.

TODOROVICH P., SCHNED D., LANE R. (2011), High-Speed Rail. International Lessons for U.S. Policy Makers, Lincoln Institute of Land Policy, Cambridge, MA.

TROIN J.-F. (1997), Les gares T.G.V. et le territoire : débat et enjeux, Annales de Géographie 106 (593), 34-50.

TROIN J.-F. (1998), Des gares TGV hors la ville : une aberration française ? Urbanisme $302,37-38$.

TROITIÑO VINUESA M. A., TROITIÑO TORRALBA L. (2009), Toledo: características y problemáticas de un destino patrimonial, in: Troitiño Vinuesa M. A. (ed.), Ciudades Patrimonio de la Humanidad: Patrimonio, Turismo y Recuperación Urbana, Universidad Internacional de Andalucía, Sevilla, pp. 216-250.

UREÑA J. M., MENERAULT P., GARMENDIA M. (2009), The high-speed rail challenge for big intermediate cities: a national, regional and local perspective, Cities 26 (5), 266-279.

VÁZQUEZ VARELA C., MARTÍNEZ NAVARRO J. M. (2015), L'implantation des gares de Grande Vitesse ferroviaire à l'écart des villes moyennes: un enjeu pour l'aménagement locale. Une analyse de deux études de cas en Espagne, Revue Géographique de l'Est 55 (34), 1-22.

VICKERMAN R. (2015), High-speed rail and regional development: the case of intermediate stations, Journal of Transport Geography 42, 157-165.

VICKERMAN R. (2016), High-Speed Rail - The European Experience, in: de Ureña J. M. (ed.), Territorial implications of high-speed rail. A Spanish perspective, Routledge, London and New York, pp. 17-31.

VICKERMAN R., SPIEKERMANN K., WEGENER M. (1999), Accessibility and economic development in Europe, Regional Studies 33 (1), 1-15.

WANG X., HUANG S., ZOU T., YAN H. (2012), Effects of the high speed rail network on China's regional tourism development, Tourism Management Perspectives 1, 34-38.

\section{Annex}

Travellers in hotel establishments by year (2005-2015) (Absolute data)

In Bold and Italic, the years served by the HSR after the opening of the HSR line and station

\begin{tabular}{|c|c|c|c|c|c|c|c|c|}
\hline & \multicolumn{5}{|c|}{$\begin{array}{l}\text { Cities with high-speed } \\
\text { railway lines and stations }\end{array}$} & \multicolumn{3}{|c|}{$\begin{array}{l}\text { Cities without high-speed } \\
\text { railway lines and stations }\end{array}$} \\
\hline & Cuenca & Toledo & $\begin{array}{l}\text { Alba- } \\
\text { cete }\end{array}$ & Segovia & $\begin{array}{l}\text { Vallado- } \\
\text { lid }\end{array}$ & Ávila & $\begin{array}{l}\text { Sala- } \\
\text { manca }\end{array}$ & Cáceres \\
\hline 2005 & 209,196 & 434,615 & 157,233 & 160,539 & 298,559 & 225,627 & 554,007 & 224,707 \\
\hline 2006 & 208,923 & 450,669 & 157,799 & 187,302 & 317,406 & 226,457 & 581,040 & 226,977 \\
\hline 2007 & 222,182 & 465,418 & 166,731 & 219,805 & 353,610 & 235,468 & 576,890 & 213,384 \\
\hline 2008 & 203,849 & 448,007 & 164,477 & 210,931 & 361,913 & 217,363 & 590,588 & 201,185 \\
\hline 2009 & 188,093 & 441,644 & 148,227 & 209,561 & 335,031 & 194,964 & 571,932 & 206,975 \\
\hline 2010 & 197,584 & 460,795 & 169,209 & 207,473 & 338,967 & 203,625 & 584,768 & 215,489 \\
\hline 2011 & 196,179 & 462,063 & 160,258 & 216,054 & 352,301 & 203,231 & 597,588 & 233,052 \\
\hline 2012 & 179,893 & 468,633 & 152,292 & 208,845 & 333,342 & 184,957 & 583,981 & 223,071 \\
\hline 2013 & 176,427 & 491,362 & 155,270 & 208,014 & 344,647 & 212,833 & 615,532 & 237,166 \\
\hline 2014 & 170,192 & 596,980 & 159,591 & 217,465 & 363,550 & 224,659 & 592,646 & 250,582 \\
\hline 2015 & 175,654 & 566,977 & 176,385 & 257,441 & 380,553 & 274,123 & 660,668 & 267,807 \\
\hline
\end{tabular}


Source: Tourist Accommodation Occupancy Survey, National Statistical Institute Overnight stays by travellers between 2005 and 2015 (Absolute data)

In Bold and Italic, the years served by the HSR after the opening of the HSR line and station

\begin{tabular}{|l|l|l|l|l|l|l|l|l|}
\hline \multicolumn{7}{|c|}{$\begin{array}{c}\text { Cities with high-speed railway } \\
\text { lines and stations }\end{array}$} & \multicolumn{3}{|c|}{$\begin{array}{c}\text { Cities without high-speed } \\
\text { railway lines and stations }\end{array}$} \\
\hline & Cuenca & Toledo & $\begin{array}{c}\text { Alba- } \\
\text { cete }\end{array}$ & Segovia & $\begin{array}{c}\text { Valla- } \\
\text { dolid }\end{array}$ & Avila & $\begin{array}{c}\text { Sala- } \\
\text { manca }\end{array}$ & Cáceres \\
\hline $\mathbf{2 0 0 5}$ & 335,417 & $\mathbf{6 7 7 , 0 6 5}$ & 257,599 & 238,090 & 508,531 & 349,341 & 922,573 & 374,069 \\
\hline $\mathbf{2 0 0 6}$ & 335,847 & $\mathbf{7 2 9 , 7 0 6}$ & 261,966 & 279,581 & 521,065 & 360,991 & 998,565 & 372,323 \\
\hline $\mathbf{2 0 0 7}$ & 367,153 & $\mathbf{7 4 2 , 0 5 4}$ & 282,178 & $\mathbf{3 4 6 , 0 1 4}$ & $\mathbf{5 5 5 , 6 3 7}$ & 376,031 & 996,131 & 342,242 \\
\hline $\mathbf{2 0 0 8}$ & 340,887 & $\mathbf{7 2 8 , 1 3 8}$ & 289,260 & $\mathbf{3 3 8 , 6 3 6}$ & $\mathbf{5 7 4 , 8 7 5}$ & 354,540 & 984,668 & 336,968 \\
\hline $\mathbf{2 0 0 9}$ & 316,474 & $\mathbf{6 9 4 , 4 8 3}$ & 237,161 & $\mathbf{3 2 9 , 8 8 8}$ & $\mathbf{5 4 8 , 0 4 4}$ & 320,307 & 943,807 & 326,971 \\
\hline $\mathbf{2 0 1 0}$ & $\mathbf{3 1 8 , 5 2 7}$ & $\mathbf{7 1 9 , 2 8 1}$ & $\mathbf{2 6 2 , 3 0 9}$ & $\mathbf{3 3 5 , 4 2 4}$ & $\mathbf{5 5 1 , 4 1 6}$ & 340,078 & 965,878 & 341,573 \\
\hline $\mathbf{2 0 1 1}$ & $\mathbf{3 0 6 , 0 6 0}$ & $\mathbf{7 1 8 , 7 4 5}$ & $\mathbf{2 3 4 , 4 9 2}$ & $\mathbf{3 2 5 , 5 6 1}$ & $\mathbf{5 8 7 , 3 7 3}$ & 335,541 & 957,292 & 368,701 \\
\hline $\mathbf{2 0 1 2}$ & $\mathbf{2 7 2 , 4 8 0}$ & $\mathbf{7 0 0 , 7 9 6}$ & $\mathbf{2 2 0 , 6 1 8}$ & $\mathbf{3 0 6 , 7 5 8}$ & $\mathbf{5 4 7 , 5 6 2}$ & 303,550 & 910,892 & 358,551 \\
\hline $\mathbf{2 0 1 3}$ & $\mathbf{2 7 6 , 9 4 7}$ & $\mathbf{7 3 8 , 5 8 6}$ & $\mathbf{2 3 2 , 7 9 5}$ & $\mathbf{2 9 6 , 9 3 4}$ & $\mathbf{5 7 2 , 3 4 1}$ & 320,074 & 953,502 & 357,326 \\
\hline $\mathbf{2 0 1 4}$ & $\mathbf{2 8 1 , 1 9 8}$ & $\mathbf{9 0 2 , 4 5 1}$ & $\mathbf{2 4 5 , 1 8 3}$ & $\mathbf{3 3 1 , 6 0 1}$ & $\mathbf{6 1 6 , 5 0 3}$ & 329,442 & 975,095 & 376,418 \\
\hline $\mathbf{2 0 1 5}$ & $\mathbf{2 9 0 , 8 5 2}$ & $\mathbf{8 4 9 , 1 3 2}$ & $\mathbf{2 6 9 , 6 2 3}$ & $\mathbf{4 0 7 , 1 9 8}$ & $\mathbf{6 5 9 , 1 5 5}$ & 422,676 & $1,062,327$ & 419,975 \\
\hline & & & & & & & & \\
\hline
\end{tabular}

Source: Tourist Accommodation Occupancy Survey, National Statistical Institute

Initial submission: 24.01.2016

Revised submission: 07.12.2016

Final acceptance: 16.12.2016

Correspondence: School of Educational Sciences and Humanities, Avda. de los Alfares 42, 16071 Cuenca, Spain

Email: carmen.vazquez@uclm.es 